\title{
Single-tree Equations for Estimating Biomass of Trembling Aspen, Large Tooth Aspen and White Birch in Ontario
}

\author{
by \\ I. S. Alemdag' ${ }^{1}$ and K. W. Horton ${ }^{2}$
}

\begin{abstract}
Ovendry mass of single trees of trembling aspen, largetooth aspen, and white birch in the Great Lakes - St. Lawrence and Boreal forest regions in Ontario was studied in relation to stem dimensions. Mass equations for tree components based on diameter at breast height outside bark and tree height were developed. Results were found more dependable for stem wood and the whole tree than for stem bark, live branches, and twigs plus leaves. Ovendry mass values were slightly higher than those reported for New York and northern Minnesota.
\end{abstract}

\section{Résumé}

On a comparé aux dimensions de leurs tiges, les poids secs absolus de peupliers faux-trembles, de peupliers à grandes dents et de bouleaux à papier de la région boréale ainsi que de la région des Grands Lacs et du Saint-Laurent. On a établi des équations de poids des éléments d'arbre selon le diamètre à hauteur d'homme, le diamètre externe et la hauteur totale. Les résultats se sont révélés plus sûrs dans les cas du bois de tige et de l'arbre entier que dans ceux de l'écorce de tige, des branches fraîches et des brindilles avec feuilles. Les poids secs absolus en questions sont légèrement supérieurs à ceux des arbres de l'État de New York et du nord du Minnesota.

\section{Introduction}

Growing concern regarding the shortage of fuel has focussed interest on renewable energy sources, prominent among which is forest biomass. In strict terms, forest biomass is the quantity of living organisms in a forest ecosystem expressed as mass ${ }^{3}$, but for practical purposes the term is generally confined to the living components of woody material-trees and shrubs. Usually, as in this report, it applies to the aboveground portions only.

If forests are to be managed for biomass production, their present and potential capacity must first be evaluated. The primary requirement is the development of functions for individual tree mass for each species. Accordingly, the purpose of this study was to formulate equations by tree components in terms of diameter at breast height outside bark (dbhob) and tree height (h) for estimating aboveground ovendry mass of trembling aspen (Populas tremuloides Michx.), largetooth aspen (Populus grandidentata Michx.), and white birch (Betula papyrifera Marsch.), applicable to two forest regions (Rowe 1972) in Ontario. These species represent a large and underutilized resource, carrying a considerable biomass potential within the province.

\footnotetext{
1I. S. Alemdag is a research scientist at the Petawawa National Forestry Institute, En. vironment Canada, Chalk River, Ontario, KOJ 1 JO.

${ }^{2}$ K. W. Horton is the president of Horton Forestry Services Ltd., R.R. 4, Stouffville, Ontario, LOH 1 LO.
} 3 Mass is used for weight in this paper, as suggested by the Canadian Standards Associa-
tion in the Canadian Metric Practice Guide, 1979.

\section{Methods}

\section{Field}

The study covered three locations in the Great Lakes St. Lawrence Forest Region, between Chalk River and Haliburton, and two broad areas near Kirkland Lake and Nipigon, representing the eastern and western portions of the Boreal Forest Region in Ontario. A total of 483 sample trees of the subject species were taken from plots of $20 \mathrm{~m} \mathrm{x}$ $20 \mathrm{~m}$ established in natural, fully stocked, even-aged, largely pure stands sampled during this biomass yield investigation ${ }^{4}$ and a previous study (Alemdag 1980b). Sample trees were selected from the full range of classes of dbhob and $h$. Twenty-eight of these trees were between $0.1 \mathrm{~cm}$ and 5.0 $\mathrm{cm}$ dbhob and the others were larger. After felling, the sample trees were separated into the components of stem, branches, and twigs plus leaves, following Alemdag's field and laboratory instructions (1980a). From each tree, the necessary dimensional measurements were taken, the components were weighed green, and samples were collected. Statistical data on some of the measurements are shown in Table 1.

\section{Laboratory}

The samples were then processed at the laboratory to establish the ovendry mass (OM)/green mass (GM) ratios for the stem wood, stem bark, live branches, and twigs plus leaves. These ratios, together with the field-measured green masses of the whole components, were used to calculate the ovendry mass of the whole components. (Stem is defined as the main bole of the tree from ground level to tip, and twigs as the leaf-bearing shoots of live branches smaller than $0.5 \mathrm{~cm}$ in diameter.)

\section{Analysis}

Ovendry mass plotted over tree size (expressed as $d_{\left.b h o b^{2} \bullet h\right)}$ suggested a strong linear correlation. An example of this, using components of trembling aspen from the Great Lakes - St. Lawrence Forest Region, can be seen in Figure 1. Because of the close relationships between ovendry mass and tree size, the following regression models were tested for ovendry mass estimates of the tree components and of the whole tree for trees $5.1 \mathrm{~cm}$ and larger in dbhob:

$$
\begin{aligned}
& O M=b_{0}+b_{1} \bullet(d b h o b)^{2}+b_{2} \bullet h+b_{3} \bullet(d b h o b)^{2} \bullet h \\
& O M=b_{1} \bullet(d b h o b)^{2}+b_{2} \bullet h+b_{3} \bullet(d b h o b)^{2} \bullet h \\
& O M=b_{0}+b_{1} \bullet(d b h o b)^{2} \bullet h \\
& O M=b_{1} \bullet(d b h o b)^{2} \bullet h
\end{aligned}
$$

where OM is expressed in kilograms, dbhob in centimetres, and $h$ in metres. The tree components are those listed above.

\footnotetext{
${ }^{4}$ Funded by the Energy from the Forest Program (ENFOR) of the Canadian Forestry Serv.
} ice. 
Table 1. Statistical data on dbhob, $\mathrm{h}$, and green mass of the whole tree for sample trees $5.1 \mathrm{~cm}$ dbhob and larger

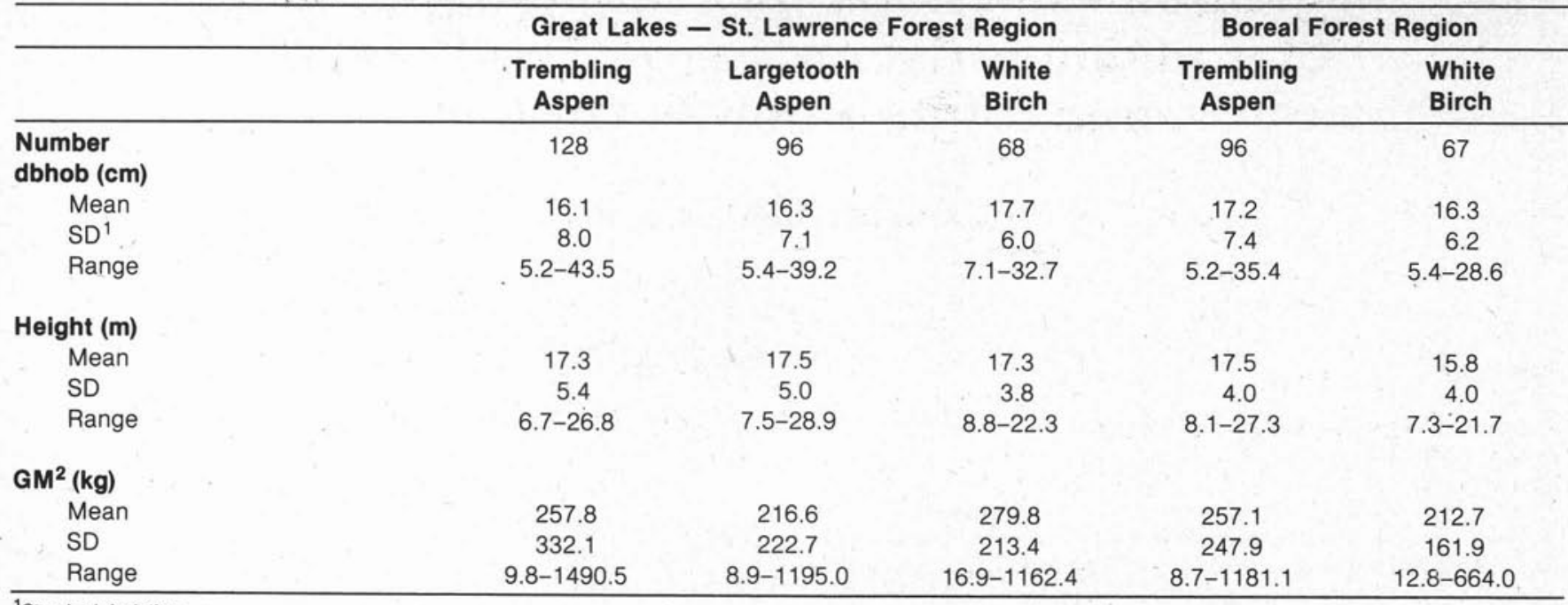

${ }^{1}$ Standard deviation.

${ }^{2}$ Green mass.

Table 2. Regression data on the prediction of ovendry mass for trees of $5.1 \mathrm{~cm}$ dbhob and larger, using the model OM $=\mathrm{b}_{1}$. (dbhob) ${ }^{2} . h$

\begin{tabular}{llllr}
\hline$b_{1}$ & $r^{2}$ & SEE\% & $\begin{array}{r}\text { Mean } \\
(\mathbf{k g})\end{array}$ & $\begin{array}{r}\text { Range } \\
(\mathbf{k g})\end{array}$ \\
\hline
\end{tabular}

(a) Great Lakes - St. Lawrence Forest Region

Trembling Aspen

$$
\text { ( } n=128)
$$

Stem wood

Stem bark

Lives branches

Twigs and leaves

Whole tree

$1.4483 \cdot 10^{-2}$
$3.4560 \cdot 10^{-3}$
$2.6715 \cdot 10^{-3}$
$4.7615 \cdot 10^{-4}$
$2.1087 \cdot 10^{-2}$

$1.3427 \cdot 10^{-2}$

$2.9314 \cdot 10^{-3}$

$1.8398 \cdot 10^{-3}$

$3.7936 \cdot 10^{-4}$

$1.8577 \cdot 10^{-2}$

Whole tree

Stem wood

Stem bark

Live branches

Twigs and leaves

Whole tree

0.979
0.936
0.811
0.585
0.976

0.976

Largetooth Aspen

$$
\text { ( } n=96)
$$

0.981
0.917
0.714
0.736
0.982

White Birch

$$
(n=68)
$$

$$
\begin{aligned}
& 1.6351 \cdot 10^{-2} \\
& 2.9578 \cdot 10^{-3} \\
& 4.1696 \cdot 10^{-3} \\
& 9.7522 \cdot 10^{-4} \\
& 2.4454 \cdot 10^{-2}
\end{aligned}
$$

18.1

34.6

77.2

62.3

20.1

13.9

28.7

76.9

54.0

13.7

10.7

15.8

82.7

33.8

12,2

(b) Boreal Forest Region

Tembling Aspen

$$
(n=96)
$$

Stem wood

Stem bark

Live branches

Twigs and leaves

Whole tree
$1.4748 \cdot 10^{-2}$
$2.7476 \cdot 10^{-3}$
$2.1939 \cdot 10^{-3}$
$5.7001 \cdot 10^{-4}$
$2.0259 \cdot 10^{-2}$
18.7

27.8

59.8

62.2

18.8
0.963
0.931
0.774
0.683
0.964

White Birch

( $n=67$ )
101.9

23.3

15.8

4.3

145.3

86.7

19.4

10.7

2.6

119.4
3.2-671.6

$0.8-160.3$

0.3-174.8

$0.3-18.5$

5.1-964.4
2.9-403.4

1.0-112.4

0.3-116.9

$0.2-20.7$

4.6-641.2
Stem wood

Stem bark

Live branches

Twigs and leaves

Whole tree
$1.6001 \cdot 10^{-2}$

$2.7467 \cdot 10^{-3}$

$2.5581 \cdot 10^{-3}$

$6.8510 \bullet 10^{-4}$

$2.1991 \cdot 10^{-2}$
0.973

0.609

0.726

0.678

0.970
104.3

18.8

14.4

4.1

141.5
4.5-350.8

$0.7-48.6$

$0.8-222.9$

$0.5-25.6$

8.0-657.1
$3.4-449.0$
$0.6-107.7$
$0.3-81.6$
$0.2-23.2$
$4.6-650.7$ 


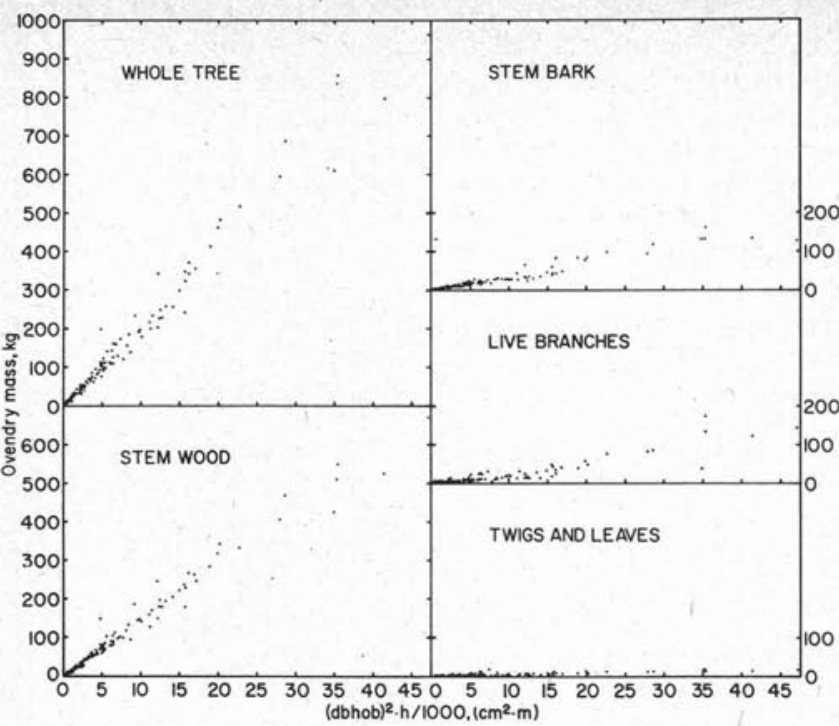

Fig. 1 Distribution of ovendry mass of components and of whole tree over $\mathrm{dbhob}^{2} \bullet \mathrm{h}$ : trembling aspen for the Great Lakes St. Lawrence Forest Region.

The regression analyses of ovendry mass of tree components revealed negligible differences among the multiple correlation coefficient $\left(R^{2}\right)$ and the standard error of estimate (SEE) figures for the four models. The coefficient of variation in all tree-size classes was essentially the same for any given tree component. For its practical simplicity, therefore, Equation 4 was adopted for trees of dbhob $5.1 \mathrm{~cm}$ and larger. This is a Standard mass-equation as opposed to a local mass-equation, which is based on dbhob alone.

Separate analyses were performed with this model for each species, samples being drawn from the two forest regions and the two boreal subregions, and for pooled data (except for largetooth aspen in the Boreal Forest Region, where the species rarely occurs). An F-test was then used to examine the significance of differences between categories.

Besides its simplicity and other properties, Equation 4 has the advantage that the ratio between the masses of any two components estimated from it is constant for all diameters anf heights. For this reason, the relative percentages of mass for the components were determined by dividing the $b_{1}$ coefficients of the equations for the components by those of the stem wood and the whole tree. These percentages were also calculated directly, employing the raw data of the sample trees of each species, with the formula

$$
\begin{aligned}
& \text { Ratio }=(\Sigma \mathrm{OM} \text { of component }) /(\Sigma \mathrm{OM} \text { of stem wood, or, } \\
& \Sigma \mathrm{OM} \text { of the whole tree) }
\end{aligned}
$$

The distribution of ovendry mass of wood within four stem sections was studied independently in order to approximate the contents of merchantable trees, using those with a 9.1-cm top diameter outside bark. The four sections were the lower, middle, and upper third of the bole from ground level to the top diameter of $9.1 \mathrm{~cm}$ (merchantable part of the stem), and the top.

A comparison of whole-tree ovendry mass of the three species was made, and, based on the same variables of $\mathrm{dbhob}$ and $\mathrm{h}$, the results of trembling aspen from the Great Lakes - St. Lawrence Forest Region were compared with the results from New York and northern Minnesota.

Trees smaller than $5.1 \mathrm{~cm}$ in dbhob and woody plants less than $1.31 \mathrm{~m}$ high were studied separately.

\section{Results}

Statistical analyses revealed that, for the form of the equation adopted (Equation 4), there is no significant difference between the two boreal subregions. However, the difference between the Great Lakes - St-Lawrence Forest Region and the Boreal Forest Region is significant (though marginally so), and for this reason the two regions were not combined. Similar significant differences prevented the combining of the two aspens. The statistical data and the regression coefficients of this equation for all species studied in the two regions can be seen in Table 2 . This combined-variable equation has the following properties:

(1) the component mass estimates add up to the independent estimate for the whole tree;

(2) is easy to apply;

(3) fits into a compatible system of equations for taper and stem volume; and

(4) is suitable for point sampling.

For trees $0.1 \mathrm{~cm}$ to $5.0 \mathrm{~cm}$ dbhob, the whole-tree ovendry mass was derived from the following equation, which combines all species in both regions:

$\mathrm{OM}=0.030+0.021107 \bullet(\mathrm{dbhob})^{2} \bullet h$

For woody plants $1.30 \mathrm{~m}$ or less high, the following average ovendry mass figures, which were established for the Petawawa area (Alemdag 1980b), were thought to be applicable also for the area covered by the present study: height from $0.31 \mathrm{~m}$ to $0.80 \mathrm{~m}, 8 \mathrm{~g} / \mathrm{stem}$; height from $0.81 \mathrm{~m}$ to $1.30 \mathrm{~m}, 22 \mathrm{~g} / \mathrm{stem}$.

The relationships between the ovendry mass and the tree size are better for the whole tree and for stem wood than for the other tree components, the relationships of the former having $r^{2}$ values over 0.97 and SEE \% values as low as $11 \%$. A similar situation was found for six hardwood species (including trembling aspen and white birch) by Alemdag (1980b) and for trembling aspen Zavitkovski (1971).

The proportions of the ovendry mass of tree components in relation to stem wood and the whole tree are provided in Table 3. These figures show that stem wood constitutes $67-73 \%$ of the total mass, stem bark $12-16 \%$, live branches $10-17 \%$, and twigs and leaves $2-4 \%$. Thus the stem with bark represents the major part $(79-88 \%)$.

When the percentages in Table 3 are compared with a second set of percentages calculated using Equation $5^{5}$, they show a very close resemblance, which in turn is an indication of the accuracy of the model chosen for the estimation of component masses.

The component percentages are useful tools when used with the ovendry mass of stem wood, particularly when the latter is estimated using inside-bark volume of single trees or of an entire stand, together with stem-wood density.

The average distribution of ovendry mass of the stem, excluding bark, is given in Table 4 . The proportional values of the mass drop from the lower third of the merchantable bole to the top section of the stem in almost the same percentage values for all species and forest regions. On the average, these are $46.4 \%, 30.8 \%, 17.5 \%$, and $5.3 \%$. The merchantable bole makes up around $95 \%$ of the stem wood.

A comparison of the three species is presented in Figure 2. It shows the relationship mass and dbhod in Great Lakes - St. Lawrence Forest Region using specific massequations of the whole tree with an average $\mathrm{h} / \mathrm{dbhod}$ curve for all species. Though the patterns are similar because of the same form of an equation, it is evident that the increase

${ }^{5}$ Although not given in Table 3, these ratios can be established by employing the mean values of components and of whole tree in Table 2. 
Table 3. Component ovendry masses in relation to stem wood and whole-tree ovendry masses

\begin{tabular}{|c|c|c|c|c|}
\hline & & $\begin{array}{l}\text { Trembling } \\
\text { Aspen }\end{array}$ & $\begin{array}{l}\text { Largetooth } \\
\text { Aspen }\end{array}$ & $\begin{array}{l}\text { White } \\
\text { Birch }\end{array}$ \\
\hline \multicolumn{5}{|c|}{ Percent of Stem Wood Ovendry Mass } \\
\hline Stem bark & $\begin{array}{l}\text { (1) } \\
(2)\end{array}$ & $\begin{array}{l}23.9 \\
18.6\end{array}$ & 21.8 & $\begin{array}{l}18.1 \\
17.1\end{array}$ \\
\hline Live branches & $\begin{array}{l}\text { (1) } \\
(2)\end{array}$ & $\begin{array}{l}18.4 \\
14.9\end{array}$ & . 13.7 & $\begin{array}{l}25.5 \\
16.0\end{array}$ \\
\hline Twigs and leaves & $\begin{array}{l}(1) \\
(2)\end{array}$ & $\begin{array}{l}3.3 \\
3.9\end{array}$ & 2.8 & $\begin{array}{l}6.0 \\
4.3\end{array}$ \\
\hline Whole tree & $\begin{array}{l}(1) \\
(2)\end{array}$ & $\begin{array}{l}145.6 \\
137.4\end{array}$ & 138.3 & $\begin{array}{l}149.6 \\
137.4\end{array}$ \\
\hline \multicolumn{5}{|c|}{ Percent of Whole-Tree Ovendry Mass } \\
\hline Stem wood & $\begin{array}{l}(1) \\
(2)\end{array}$ & $\begin{array}{l}68.7 \\
72.8\end{array}$ & 72.3 & $\begin{array}{l}66.9 \\
72.8\end{array}$ \\
\hline Stem bark & $\begin{array}{l}(1) \\
(2)\end{array}$ & $\begin{array}{l}16.4 \\
13.6\end{array}$ & 15.8 & $\begin{array}{l}12.1 \\
12.5\end{array}$ \\
\hline Live branches & $\begin{array}{l}(1) \\
(2)\end{array}$ & $\begin{array}{l}12.7 \\
10.8\end{array}$ & 9.9 & $\begin{array}{l}17.0 \\
11.6\end{array}$ \\
\hline Twigs and leaves & $\begin{array}{l}(1) \\
(2)\end{array}$ & $\begin{array}{l}2.2 \\
2.8 \\
\end{array}$ & 2.0 & $\begin{array}{l}4.0 \\
3.1\end{array}$ \\
\hline
\end{tabular}

(1) Great Lakes - St. Lawrence Forest Region;

(2) Boreal Forest Region.

Table 4. Percentage distribution of ovendry mass of wood within stem ${ }^{1}$

\begin{tabular}{lrrrrrr}
\hline & \multicolumn{2}{c}{$\begin{array}{c}\text { Trembling } \\
\text { Aspen }\end{array}$} & $\begin{array}{c}\text { Largetooth } \\
\text { Aspen }\end{array}$ & White & Birch \\
\hline & (a) & (b) & (a) & (a) & (b) \\
& $\mathbf{n = 8 6}$ & $\mathbf{n = 7 9}$ & $\mathbf{n = 7 1}$ & $\mathbf{n = 5 3}$ & $\mathbf{n = 5 0}$ \\
\hline Lower third of merch. bole & 46.4 & 44.4 & 47.1 & 48.2 & 45.9 \\
Middle third of merch. bole & 31.4 & 32.2 & 30.1 & 30.6 & 29.9 \\
Upper third of merch. bole & 17.6 & 17.5 & 17.5 & 16.6 & 18.0 \\
Tree Top & 4.6 & 5.9 & 5.3 & 4.6 & 6.2 \\
\hline & Total & 100.0 & 100.0 & 100.0 & 100.0 & 100.0 \\
\hline
\end{tabular}

1 Includes stump, excludes bark.

(a) Great Lakes - St. Lawrence Forest Regions;

(b) Boreal Forest Region.

Table 5. Whole-tree mass estimates for trembling aspen using three different equations reported by (1) the present study for the Great Lakes - St. Lawrence Forest Region, (2) Monteith (1979) for New York, and (3) Schlaegel (1975) for northern Minnesota

\begin{tabular}{ccrcrcc}
\hline \multicolumn{7}{c}{$\begin{array}{c}\text { Whole-tree mass } \\
\text { (kg) }\end{array}$} \\
\hline $\begin{array}{c}\text { dbhob Height } \\
\text { (cm) }\end{array}$ & (m) & $\mathbf{( 1 )}$ & $\mathbf{( 2 )}$ & $\mathbf{( 3 )}$ & $\mathbf{( 1 ) / ( 2 )}$ & $\mathbf{( 1 ) / ( 3 )}$ \\
\hline 5 & 7 & 3.7 & - & 3.4 & - & 1.09 \\
10 & 12 & 25.3 & 22.6 & 23.2 & 1.12 & 1.09 \\
15 & 16 & 75.9 & 72.4 & 68.7 & 1.03 & 1.10 \\
20 & 19 & 160.3 & 156.0 & 143.9 & 1.03 & 1.11 \\
25 & 21 & 276.8 & 272.8 & 247.2 & 1.01 & 1.12 \\
30 & 22 & 417.5 & 415.8 & 371.4 & 1.00 & 1.12 \\
\hline
\end{tabular}

in mass with dbhob is greatest in white birch and least in largetooth aspen. The ovendry mass of the whole tree of trembling aspen is 1.14 times, and of white birch 1.32 times, that of largetooth aspen of the same size. The ratio of the total mass of white birch to that of trembling aspen is 1.16.

The results with the trembling aspen whole-tree equation developed in this study for the Great Lakes - St. Lawrence Forest Region compare favourably with results reported in New York (Monteith 1979) and in northern Minnesota (Schlaegel 1975), although ranging up to $12 \%$ higher (Table 5). In general, however, this indicates that the tree mass of these species is reasonably constant over a large part of their range.

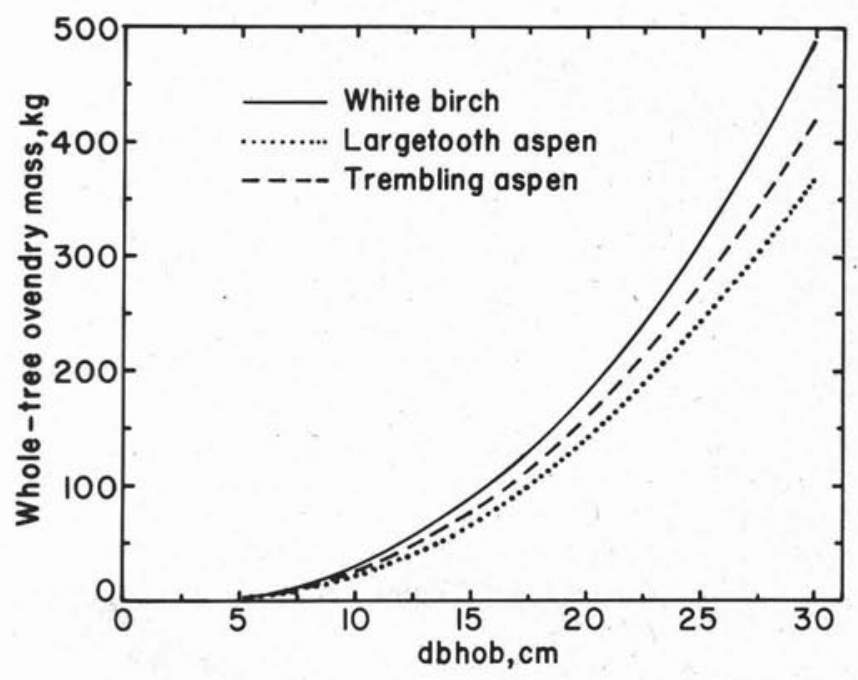

Fig. 2 Trends of whole-tree ovendry mass of the three species in the Great Lakes - St. Lawrence Forest Region.

\section{Applications}

The equations given here for estimating aboveground ovendry mass of the whole tree and of its components for trembling aspen, largetooth aspen, and white birch are obviously best applied to single trees in the Ontario portions of the Great Lakes - St. Lawrence and Boreal forest regions, where the data were collected. However, based as they are on dbhob and $h$, they may be used reliably in ecologically similar areas. Because the estimates of mass of the components, using their own equations, add up to the whole-tree mass, that mass can be determined either by its own equation or by summing the values from the component equations. If, however, the dimensions are lacking but the insidebark stem volume of a tree or of a stand is known, then the ovendry mass of stem wood can be calculated by using this volume and the species' wood density. Whole-tree and component masses can then be found by employing the percentages given in Table 3. By employing those in Table 4, the distribution of mass in a stem can be determined for utilization purposes.

For stand estimates of aboveground ovendry mass by the use of stand data and these equations, calculations could be based on any of the following variables:

(1) single-tree dbhob and $\mathrm{h}$ data of full inventory;

(2) single-tree $d b h o b$ and corresponding $h$ values from the stand $\mathrm{h} / \mathrm{dbhob}$ curve;

(3) mean dbhob (quadratic mean) and mean $\mathrm{h}$ of each diameter class together with the number of trees per 
class (h can be either Lorey's height or from the stand h/dbhob curve);

(4) mean dbhob (quadratic mean) and mean h of the stand together with total number of trees in the stand (h can be either Lorey's height or taken from the stand $\mathrm{h} / \mathrm{dbhob}$ curve); and

(5) in point sampling, basal area per hectare $\left(G, m^{2}\right)$ and mean $\mathrm{h}$ of the stand, using the modified ovendry mass formula OM/ha $=\left(40000 \bullet b_{1} / \pi\right) \bullet G \bullet h$.

Woody plants less than $1.31 \mathrm{~m}$ high should be evaluated from their mass/stem figures, provided herein.

Tables of ovendry mass by dbhob and h class, tree component, species, and forest region, derived from the equations presented in this paper, are available on request from the Petawawa National Forestry Institute, Chalk River, Ontario KOJ $1 \mathrm{JO}$

\section{Acknowledgement}

The authors wish to extend their appreciation to Mr. T. L. Pickett, Scientific Programmer/Analyst, Petawawa National Forestry Institute for his assistance in doing the computer analyses.

\section{Lost Members}

Last known address as shown. Can you help?

A. Aiking, 199 Academy Dr., Apt. 301, Thunder Bay, Ont. P7B 5W2

Carolynn J. Anderson, 5336 Elm St., Vancouver, B.C. V6N 1 A1

P. C. Anderson, 9916 - 77 St., Edmonton, Alta. T6A 3B7

M. Ardenne, 257 Riverside Dr., Oakville, Ont. L6K 3N1

D. N. Bacala, 429 Allard, Winnipeg, Man. R3K 1T1

V. P. Bender, c/o Burn, Great Lakes Products, Box 160 Ignace, Ont. POT 1TO

W. Bientjes, 5474 Monarch St., Burnaby, B.C. V5G 2 A1

V. E. Bradford, Box 895, Ignace, Ont. POT 1 TO

D. G. Brand, 740 Gilford St., Vancouver, B.C. V6G 2 N4

B. E. Burghardt, \#2-12918 - 118 Ave. Edmonton, Alta. T5L 2L4

P. J. G. Collins, Selkirk College, Box 1200, Castlegar, B.C. V1N 3J1

G. N. Dalrymple, 4-424 - 10th St. E., Saskatoon, Sask. S7N 0C9

G. A. Dick, 9818 - 78 Ave., Grande Prairie, Alta. T8V 4V6

H. A. Erickson, General Delivery, Macdowall, Sask. SOK 2 SO

R. W. Evered, Apt. 118 - 100 Seagram Dr., Waterloo, Ont. N2L $3 \mathrm{~B} 8$

R. Greet, 176 Windemere St., Thunder Bay, Ont. P7B 3R4

John Hugues, 70 N. Ranelagh Ave., Burnaby, B.C. V5B $1 \mathrm{H} 6$

H. B. Jensen, Box 152, Gold River, B.C. T6J OL7

A. M. S. Jones, 406-237 Bath Rd., Kingston, Ont. K7M 2X8

B. Juneau, 2976 Place Dompierre, Ste. Foy, P.Q. G1X 1E1

J. K. Kelly, 48-455 SW Marine Dr., Vancouver, B.C. V5X 2R9

A. D. J. Ker, \#502-1686 W. 12th Ave., Vancouver, B.C. V6J 2E4

T. K. Killins, 102 Seagram Dr., Apt. 203. Waterloo, Ont. N2L 3B8

D. J. McCrea, Riverview Dr., R.R. 3, Fredericton, N.B. E3B 4X4

B. J. Murphy, 216-5951 Balsam St., Vancouver, B.C. V6M 4C3

K. K. Nielson, 19 Marshall St., Thunder Bay, Ont. P7A 679

J. A. Osborne, 107 Colborne St., Apt. 505, Lindsay, Ont. K9V 3T4

R. W. Parker, \#308-916 Memorial Dr., Calgary, Alta.

J. R. Patch, 488 Charlotte St., Apt. 2, Fredericton, N.B. E3B 5V7

M. C. Pedersen, 202 Parkside Dr., Apt. 14, Fredericton, N.B. E3B $5 \mathrm{~V} 7$

R. W. Reid, CFS, $5320-122$ St., Edmonton, Alta. T6H 3 S5

C. R. Rogers, 5 Devonshire Place, Toronto, Ont. N5S 2C3

E. A. Sauder, 101-2174 York St., Vancouver, B.C. V6K 1 C3

M. A. SAYERS, 2B - 9113-112 St., Edmonton, Alta. T6G 2L5

S. D. Somers, 66A North St., Perth, Ont. K7H 2T2

Diane L. Stuart, Apt. 104-418 N. Ave., Williams Lake, B.C. V2G 2E4

M. G. Taylor, Faculty of Forestry, University of Toronto, Toronto, Ont. M5S $1 \mathrm{~A} 1$

\section{References}

Alemdag, I. S. 1980a. Manual of data collection and processing for the development of forest biomass relationships. Can. For. Serv., Pet. Nat. For. Inst., Inf. Rep. PI-X-4, 38 pp.

Alemdag, I. S. 1980b. Aboveground-mass equations for six hardwood species from natural stands of the research forest at Petawawa. Can. For. Serv., Pet. Nat. For. Inst., Inf. rep. PI-X-6, 9 pp. In press.

Monteith, D. B. 1979. Whole tree weight tables for New York. State Univ. NY, Appl. For. Res. Inst., Res. Rep. No. 40, 64 pp.

Rowe, J. S. 1972. Forest regions of Canada. Can. Dept. Environ. Can. For. Serv. Publ. 1300, 172 pp.

Schlaegel, B. E. 1975. Estimating aspen volume and weight for individual trees, diameter classes, or entire stands. USDA For. Serv., NCFES, Gen. Tech. Rep. NC-20, 16 pp.

Zavitkovski, J. 1971. Dry weight and leaf area of aspen trees in northern Wisconsin. In Forest biomass studies. IUFRO. International Union of Forest Research Organizations. Life Sciences and Agriculture Experiment Station, U. of Maine at Orono. pp. 193-205.

A. C. Treadway, Apt. 7A, Park W., 2366 Portage Ave., Winnipeg, Man. R3J OM8

B. Voldock, Box 548, Barry's Bay, Ont. K0J 1B0

D. G. Walsh, Box 499, Port Alice, B.C. VON 2 NO

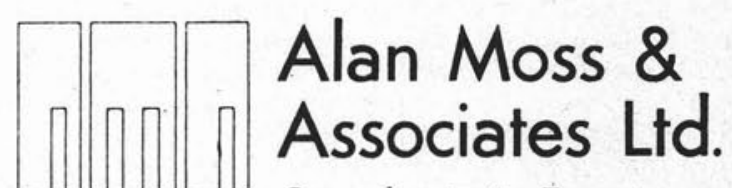

\section{Consultants in Forestry and Forest Industries}

\section{Domestic and International}

\author{
1334 St. Paul Street \\ Kelowna, British Columbia V1Y 2E1 \\ Telephone: (604) 763-4811 \\ Cable: Sylva
}

